\title{
Detection of siderophores in endophytic bacteria Methylobacterium spp. associated with Xylella fastidiosa subsp. pauca
}

\author{
Paulo Teixeira Lacava( ${ }^{(1)}$, Maria Estela Silva-Stenico ${ }^{(2)}$, Welington Luiz Araújo(1), Ana Valéria Colnaghi Simionato ${ }^{(3)}$, \\ Emanuel Carrilho(3), Siu Mui Tsai( ${ }^{(2)}$ and João Lúcio Azevedo ${ }^{(1)}$
}

\begin{abstract}
(1)Escola Superior de Agricultura Luiz de Queiroz, Departamento de Genética, Caixa Postal 83, CEP 13400-970 Piracicaba, SP, Brazil. E-mail: ptlacava@esalq.usp.br, wlaraujo@esalq.usp.br, jazevedo@esalq.usp.br (2)Centro de Energia Nuclear na Agricultura, Laboratório de Biologia Celular e Molecular, Caixa Postal 96, CEP 13400-970 Piracicaba, SP, Brazil. E-mail: estela@cena.usp.br, tsai@cena.usp.br (3)Instituto de Química de São Carlos, Departamento de Química e Física Molecular, Caixa Postal 780, CEP 13560-970 São Carlos, SP, Brazil. E-mail: avsimionato@pq.cnpq.br, emanuel@iqsc.usp.br
\end{abstract}

\begin{abstract}
The objective of this work was to study the production of siderophores by endophytic bacteria Methylobacterium spp., which occupy the same ecological niche as Xylella fastidiosa subsp. pauca (Xfp) in citrus plants. The siderophore production of Methylobacterium strains was tested according to chromeazurol agar assay test (CAS), Csáky test (hydroxamate-type) and Arnow test (catechol-type). In addition, the ability of $X f p$ to use siderophores, in vitro, produced by endophytic bacteria as source of iron, was evaluated. All 37 strains of Methylobacterium spp. tested were CAS-positive for siderophore production. Methylobacterium spp. produced hydroxamate-type, but not catechol-type siderophores. In vitro growth of $X f p$ was stimulated by the presence of supernatant siderophores of endophytic Methylobacterium mesophilicum.
\end{abstract}

Index terms: citrus variegated chlorosis, endophytes, heterologous siderophores, iron, symbionts.

\section{Detecção de sideróforos nas bactérias endofíticas Methylobacterium spp. associadas com Xylella fastidiosa subsp. pauca}

\begin{abstract}
Resumo - O objetivo deste trabalho foi estudar a produção de sideróforos pelas bactérias endofíticas Methylobacterium spp., que ocupam o mesmo nicho ecológico que Xylella fastidiosa subsp. pauca (Xfp), em plantas cítricas. A produção de sideróforos, pelas linhagens de Methylobacterium, foi testada por meio do ensaio de cromoazarol-ágar (chromeazurol agar assay-CAS), teste de Csáky (tipo hidroxamato) e do teste de Arnow (tipo catecol). Além disso, a habilidade de $X f p$ em utilizar sideróforos produzidos por bactérias endofíticas, como fonte de ferro, in vitro, foi avaliada. Todas as 37 linhagens de Methylobacterium spp. testadas foram positivas para a produção de sideróforos, pelo teste CAS-ágar. Methylobacterium spp. foram capazes de produzir sideróforos do tipo hidroxamato, mas não do tipo catecol. O crescimento in vitro de Xfp foi estimulado pela presença de sideróforos no sobrenadante de Methylobacterium mesophilicum endofítica.
\end{abstract}

Termos para indexação: clorose variegada dos citros, endófitos, sideróforos heterólogos, ferro, simbiose.

\section{Introduction}

Endophytes are microorganisms which do not visibly harm the host plant, but can be isolated from the internal tissues of surface-disinfected plants (Azevedo et al., 2000; Araújo et al., 2002). Furthermore, as they colonize an ecological niche similar to certain plant pathogens, they are likely candidates for biocontrol agents (Lacava et al., 2007).

Bacterial siderophores are low-molecular-weight compounds with high $\mathrm{Fe}^{3+}$ chelating affinity (Sharma \&
Johri, 2003) responsible for the solubilization and transport of this element into bacterial cells. Some bacteria produce hydroxamate-type siderophores, while others produce catecholate-types (Neilands \& Nakamura, 1991). In a state of iron limitation, the siderophore-producing microorganisms are also able to bind and transport the iron-siderophore complex by the expression of specific proteins (Nachin et al., 2001; Nudel et al., 2001). The production of siderophores by microorganisms is beneficial to plants, because it can inhibit the growth of plant pathogens (Sharma \& Johri, 2003). In addition, iron is a 
vital element, and its sequestration by specific bacterial siderophores may induce the development of plant disease (Masclaux \& Expert, 1995; Nachin et al., 2001; Etchegaray et al., 2004).

Xylella fastidiosa subsp. pauca is the causal agent of citrus variegated chlorosis (CVC), which is an important disease of citrus species (Schaad et al. 2004). In Brazil, over 70 million sweet-orange trees (38\%) are affected, and CVC is responsible for losses of US\$ 100 million per year by Brazilian citrus industries, besides affecting all commercial sweet-orange varieties (Souza et al., 2005). X. fastidiosa subsp. pauca (Xfp) was the first plant pathogen to have its genome completely sequenced, and putative genes for membrane receptors, including siderophores, were found (Simpson et al., 2000).

The genus Methylobacterium, which occupies the same ecological niche as Xfp, was the most frequently isolated endophytic bacterium from CVC-symptomatic citrus plants (Citrus sinensis) (Araújo et al., 2002; Lacava et al., 2004, 2006a, 2006b). Recently, an interaction between Methylobacterium species and Xfp was strongly indicated (Araújo et al., 2002; Lacava et al., 2004). Lacava et al. (2004) suggested that CVC symptoms in citrus plants could be a result of the population balance between endophytic bacteria Methylobacterium spp., Curtobacterium flaccumfaciens and Xfp.

Acquisition of iron from siderophores produced by other microbial species has already been described for bacteria such as Escherichia coli, Salmonella typhimurium (Martinez et al., 1990), Actinobacillus pleuropneumoniae (Diarra et al., 1996), Streptomyces sp. (Imbert et al., 1995), Arthrobacter flavescens (Winkelmann, 1991). Certain strains of Pseudomonas spp. can also utilize ferric complexes of pyoverdinessiderophores produced by other strains of Pseudomonas spp., due to the presence of multiple outer membrane receptors that recognize heterologous pyoverdines (Koster et al., 1995). Furthermore, Pseudomonas spp. can utilize iron complexes of different siderophores produced by fungi and bacteria (Meyer, 1992). These include the catechol, enterobactin (Poole et al., 1990) and the hydroxamate, aerobactin, which are produced by members of the Enterobacteriaceae family. In addition, Loper \& Henkels (1999) described the ability of Pseudomonas putida to use heterologous siderophores produced by rhizosphere microorganisms in its natural habitat.
Methylobacterium is the most frequently found genus associated to Xfp, and there is a positive association with the occurrence and intensity of symptoms of CVC (Araújo et al., 2002; Lacava et al., 2004). This interaction may occur by Methylobacterium spp. synthesis of pathological factors, such as siderophores, which may be used by Xfp (Simionato et al., 2006).

The aim of this study was to evaluate the production of siderophores by Methylobacterium spp., isolated as citrus endophytic bacteria (Araújo et al., 2002), and to investigate the $X f p$ capacity of using siderophores produced by $M$. mesophilicum for growth and development.

\section{Materials and Methods}

Methylobacterium strains used in this study are part of the collection of the Department of Genetics from Escola Superior de Agricultura Luiz de Queiroz Universidade de São Paulo, Brazil. The 37 Methylobacterium spp. strains tested are listed in Table 1, and Xfp strains used in this study were 9a5c (Simpson et al., 2000) and 6570 (Marucci et al., 2003).

The chromeazurol (CAS) agar assay was described by Schwyn \& Neilands (1987), and was modified by SilvaStenico et al. (2005). Briefly, $60.5 \mathrm{mg}$ of CAS was dissolved in $50 \mathrm{~mL}$ of deionised water, and mixed with $10 \mathrm{~mL}$ of a $\mathrm{Fe}^{3+}$ solution $\left(1 \mathrm{mmol} \mathrm{L}-1 \mathrm{FeCl}_{3} \cdot 6 \mathrm{H}_{2} \mathrm{O}\right.$, $10 \mathrm{mmol} \mathrm{L}^{-1} \mathrm{HCl}$ ). While stirring, this solution was slowly mixed with $72.9 \mathrm{mg}$ of hexadecyltrimethylammonium bromide (HDTMA) previously dissolved in $40 \mathrm{~mL}$ water. The resulting dark-blue solution was autoclaved, cooled to $50 / 60^{\circ} \mathrm{C}$ and mixed with $900 \mathrm{~mL}$ sterile MM9 (SilvaStenico et al., 2005) containing $15 \mathrm{~g} \mathrm{~L}^{-1}$ agar (also kept at $50 / 60^{\circ} \mathrm{C}$ ). This medium was allowed to gel on Petri dishes, was subsequently inoculated with bacterial strains and incubated in the dark $\left(28^{\circ} \mathrm{C}\right.$ for 5 days). Positive results were indicated by the formation of a clear halo around the colonies, showing a visual change in color from darkblue to yellow. Each assay was performed in triplicate.

Catechol-type siderophores were measured in culture supernatants through Arnow assay (Arnow, 1937), while hydroxamate siderophores were measured according to Csáky (1948). In the analyses, 2,3-dihydroxybenzoic acid and hydroxylamine hydrochloride, respectively, were used as standards. Each assay was performed in triplicate.

The ability of $X$. fastidiosa to use siderophores produced by endophytic bacteria as source of iron, in vitro, was evaluated. Two strains (AR5.1/5 and AR5.1/6) 
of the endophytic bacterium M. mesophilicum (Table 1) were individually grown in Fe-free MM9 broth (SilvaStenico et al., 2005) to the mid-log phase, to stimulate the production of siderophores, before being pelleted by centrifugation at 3,000 $\mathrm{g}$ for $5 \mathrm{~min}$. Then the supernatant was collected and filtered through a $0.22 \mu \mathrm{m}$ membrane filter. The supernatant was then added to individual preparations of PW broth medium without a source of iron (hemin chloride). The supernatant was added to a final concentration of $0.2,2,20,100 \%(\mathrm{v} / \mathrm{v})$ to produce supplemented PW broth medium (Davis et al., 1981) containing M. mesophilicum supernatant-siderophore (PWSMm).

Supplemented, unsupplemented (without a source of iron/negative control) and PW broth (positive control) were inoculated with $X f p$ by placing $9 \mathrm{~mL}$ of PWSMm in a $30 \mathrm{~mL}$ tube, and adding $1 \mathrm{~mL}$ of PW broth containing $10^{4}$ viable $X f p$ cells (previously grown at $28^{\circ} \mathrm{C}$ for 24 hours with agitation) (Lacava et al., 2004). After inoculation, the tubes were incubated at $28^{\circ} \mathrm{C}$ for 20 days, and the growth of Xfp was evaluated at $\lambda=600 \mathrm{~nm}$ using an Ultrospec 3000 spectrophotometer. Each assay was performed in triplicate.
Analysis of the data was carried out using SAS software package, with a completely randomized analysis of the variances $(\mathrm{p}<0.05)$. Tukey test was used for comparison of the means.

\section{Results and Discussion}

All strains of Methylobacterium spp. were CASpositive for siderophores production (Table 2), and the CAS-agar assay revealed that $66 \% \mathrm{CVC}$-symptomatic, $55 \%$ uninfected, $20 \%$ asymptomatic and $10 \%$ tangerine strains of Methylobacterium spp. showed very high siderophore production.

A positive siderophore reaction by the CAS method shows a yellow halo surrounding the bacterial colonies grown under iron-limiting conditions (Schwyn \& Neilands, 1987). This is the most universal assay developed so far for siderophores; it only depends on the ability of the compound to bind iron with relatively high affinity, as can see in Figure 1 for AR5.1/5, AR5.1/6, and AR1.6/2 strains of Methylobacterium.

All strains of Methylobacterium spp. were negative in the Arnow assay (Arnow, 1937), which means that

Table 1. Endophytic Methylobacterium strains collected in citrus variegated chlorosis (CVC) symptomatic, asymptomatic and uninfected plants.

\begin{tabular}{|c|c|c|c|}
\hline Plant host category & Methylobacterium species & Strains & Origin $^{(1)}$ \\
\hline C. sinensis & $\begin{array}{l}\text { M. mesophilicum } \\
\text { M. mesophilicum } \\
\text { M. mesophilicum } \\
\text { M. mesophilicum } \\
\text { M. extorquens } \\
\text { Methylobacterium sp. }\end{array}$ & \begin{tabular}{l}
\multicolumn{1}{c}{ CVC-symptomatic } \\
AR1.6/1, AR1.6/6 \\
AR3/20 \\
AR4/19 \\
AR5/1, AR5.1/4, AR5.1/5, AR5.1/6 \\
AR1.6/2, AR1.6/3, AR1.6/8, AR1.6/11 \\
AR1.6/4
\end{tabular} & $\begin{array}{l}\text { Novais } \\
\text { Catanduva } \\
\text { Frutal } \\
\text { Colina } \\
\text { Novais } \\
\text { Novais } \\
\end{array}$ \\
\hline C. sinensis & $\begin{array}{l}\text { M. mesophilicum } \\
\text { M. mesophilicum }\end{array}$ & \begin{tabular}{l}
\multicolumn{1}{c}{ CVC-asymptomatic } \\
ER1/21, ER1.6/1, ER1.6/4, ER1.6/5 \\
ER5/2
\end{tabular} & $\begin{array}{l}\text { Novais } \\
\text { Colina }\end{array}$ \\
\hline C. reticulata & $\begin{array}{l}\text { M. mesophilicum } \\
\text { M. mesophilicum } \\
\text { M. extorquens } \\
\text { M. extorquens } \\
\text { M. radiotolerans } \\
\text { M. zatmanii } \\
\text { M. mesophilicum } \\
\text { M. mesophilicum } \\
\text { M. mesophilicum } \\
\text { M. mesophilicum } \\
\text { M. fujisawaense } \\
\text { M. zatmanii }\end{array}$ & $\begin{array}{l}\text { Uninfected } \\
\text { SR1.6/6, SR1.6/13 } \\
\text { SR3/27 } \\
\text { SR1.6/1, SR1.6/15 } \\
\text { SR5/4 } \\
\text { SR1.4/10, SR1.6/4 } \\
\text { SR1.6/2 } \\
\text { PR1/3 } \\
\text { PR1.4/10 } \\
\text { PR2/2 } \\
\text { PR3/5, PR3/11, PR3/15 } \\
\text { PR5/4, PR5.1/1 } \\
\text { PR3/8, PR3/17 }\end{array}$ & $\begin{array}{l}\text { Novais } \\
\text { Catanduva } \\
\text { Novais } \\
\text { Colina } \\
\text { Novais } \\
\text { Novais } \\
\text { Novais } \\
\text { Novais } \\
\text { Elisiário } \\
\text { Catanduva } \\
\text { Colina } \\
\text { Catanduva }\end{array}$ \\
\hline
\end{tabular}

(1) All the sites are in São Paulo State, except for Frutal, which is in Minas Gerais State, Brazil. 
Table 2. Siderophore production by endophytic Methylobacterium strains ${ }^{(1)}$.

\begin{tabular}{|c|c|c|c|}
\hline Strain & $\begin{array}{c}\text { CAS-Agar } \\
\text { universal test }\end{array}$ & $\begin{array}{c}\text { Csáky test } \\
\text { (hydroxamate-type) }\end{array}$ & $\begin{array}{c}\text { Arnow test } \\
\text { (catechol-type) }\end{array}$ \\
\hline AR1.6/1 & + & + & - \\
\hline AR1.6/6 & +++ & ++ & - \\
\hline AR3/20 & ++ & + & - \\
\hline AR4/19 & + & + & - \\
\hline AR5/1 & ++ & + & - \\
\hline AR5.1/4 & +++ & + & - \\
\hline AR5.1/5 & +++ & +++ & - \\
\hline AR5.1/6 & +++ & ++ & - \\
\hline AR1.6/2 & + & + & - \\
\hline AR1.6/3 & +++ & + & - \\
\hline AR1.6/8 & +++ & + & - \\
\hline AR1.6/11 & ++ & + & - \\
\hline AR1.6/4 & + & + & - \\
\hline ER1/21 & + & + & - \\
\hline ER1.6/1 & + & + & - \\
\hline ER1.6/4 & ++ & ++ & - \\
\hline ER1.6/5 & +++ & + & - \\
\hline $\mathrm{ER} 5 / 2$ & ++ & + & - \\
\hline SR1.6/6 & +++ & + & - \\
\hline SR1.6/13 & ++ & ++ & - \\
\hline $\mathrm{SR} 3 / 27$ & ++ & ++ & - \\
\hline SR1.6/1 & +++ & + & - \\
\hline SR1.6/15 & ++ & + & - \\
\hline SR5/4 & ++ & ++ & - \\
\hline SR1.4/10 & +++ & ++ & - \\
\hline SR1.6/4 & +++ & + & - \\
\hline SR1.6/2 & +++ & + & - \\
\hline $\mathrm{PR} 1 / 3$ & + & + & - \\
\hline PR1.4/10 & +++ & + & - \\
\hline $\mathrm{PR} 2 / 2$ & + & + & - \\
\hline PR3/5 & + & + & - \\
\hline PR3/11 & ++ & ++ & - \\
\hline PR3/15 & + & + & - \\
\hline PR5/4 & + & + & - \\
\hline PR5.1/1 & ++ & + & - \\
\hline PR3/8 & ++ & ++ & - \\
\hline PR3/17 & ++ & + & - \\
\hline
\end{tabular}

${ }^{(1)}$ The symbols represent the relationship between the halo average diameter and the average diameter of the colony growth (+: small; ++: medium; +++: big) for CAS-Agar univesal test, and the intensity of production of siderophores (-: none; +: low; ++: high; +++: very high) for Csáky and Arnow tests. these strains are negative for catechol-type siderophores (Table 2). However, all strains of Methylobacterium spp. were able to produce hydroxamate-type to various degrees, as shown by the Csáky assay (Csáky, 1948) (Table 2).

Growth of Xfp strains 9a5c and 6570, in PW broth medium, was stimulated by the presence of M. mesophilicum supernatants that contained siderophores (Figure 2); and inhibition of this same strain was observed in the negative control (PW broth medium without a source of iron) (Figure 2).

The competition for iron and the high-affinity iron uptake involved in pathogenesis have been well documented in relation to animal-bacterial pathogen systems; but their role in plant pathogens has received limited attention (Banuett, 1995).

Members of genus Methylobacterium, which are frequently isolated as endophytes from citrus plants with CVC symptoms (Araújo et al., 2002; Lacava et al., 2004), are able to produce siderophores. Silva-Stenico et al. (2005) reported that one strain of M. extorquens, isolated from C. sinensis (Araújo et al., 2002), was able to produce siderophores. Also, the same authors reported that this $M$. exorquens strain was positive for hydroxamate and negative for catechol-type siderophores.

It was detected a high production of siderophores by $M$. mesophilicum and M. extorquens. Furthermore, the high levels of siderophore production were grouped in Methylobacterium species isolated from both CVC-symptomatic and healthy citrus plants. Simionato et al. (2006) characterized siderophores, produced by M. mesophilicum (AR5.1/5 and AR5.1/6 strains) and M. extorquens (AR1.6/2 strain), by capillary electrophoresis with mass spectrometry detection (CE-ESI-MS). These authors revealed siderophores with $\mathrm{m} / \mathrm{z}$ (mass-to-charge ratio)
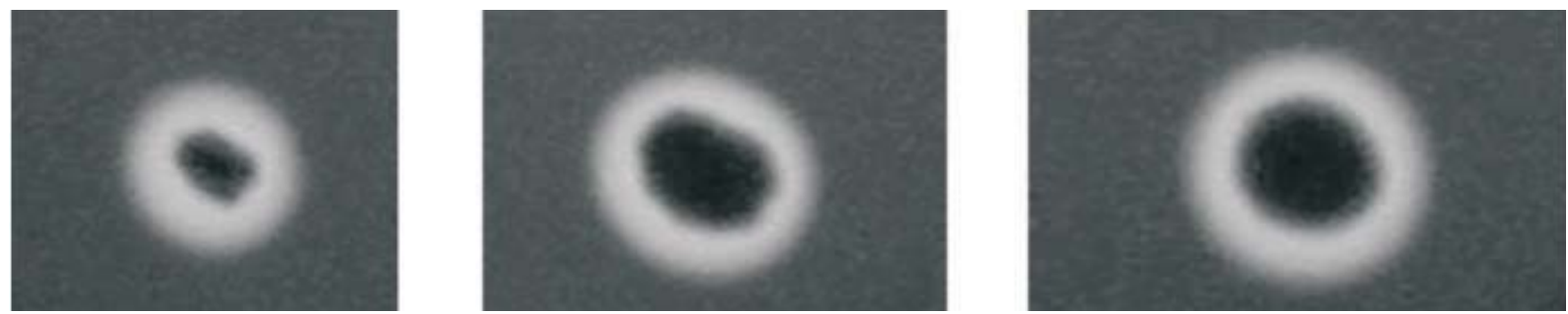

Figure 1. Chromeazurol S agar test, for siderophore detection in a plate culture of Methylobacterium spp. The culture medium with CAS blue dye contains halos indicating the presence of siderophores. 
of 1,004.3, for M. mesophilicum, and $\mathrm{m} / \mathrm{z}$ of 798.3 for M. extorquens. Mass-to-charge ratio $(\mathrm{m} / \mathrm{z})$ is used to denote the dimensionless quantity formed by dividing the mass number of an ion by its charge number.
The presence of putative open-reading frames (ORFs), encoding iron uptake in the genome of $X f p$ (Simpson et al., 2000), suggests a potential role for chelating agents in the development of the disease
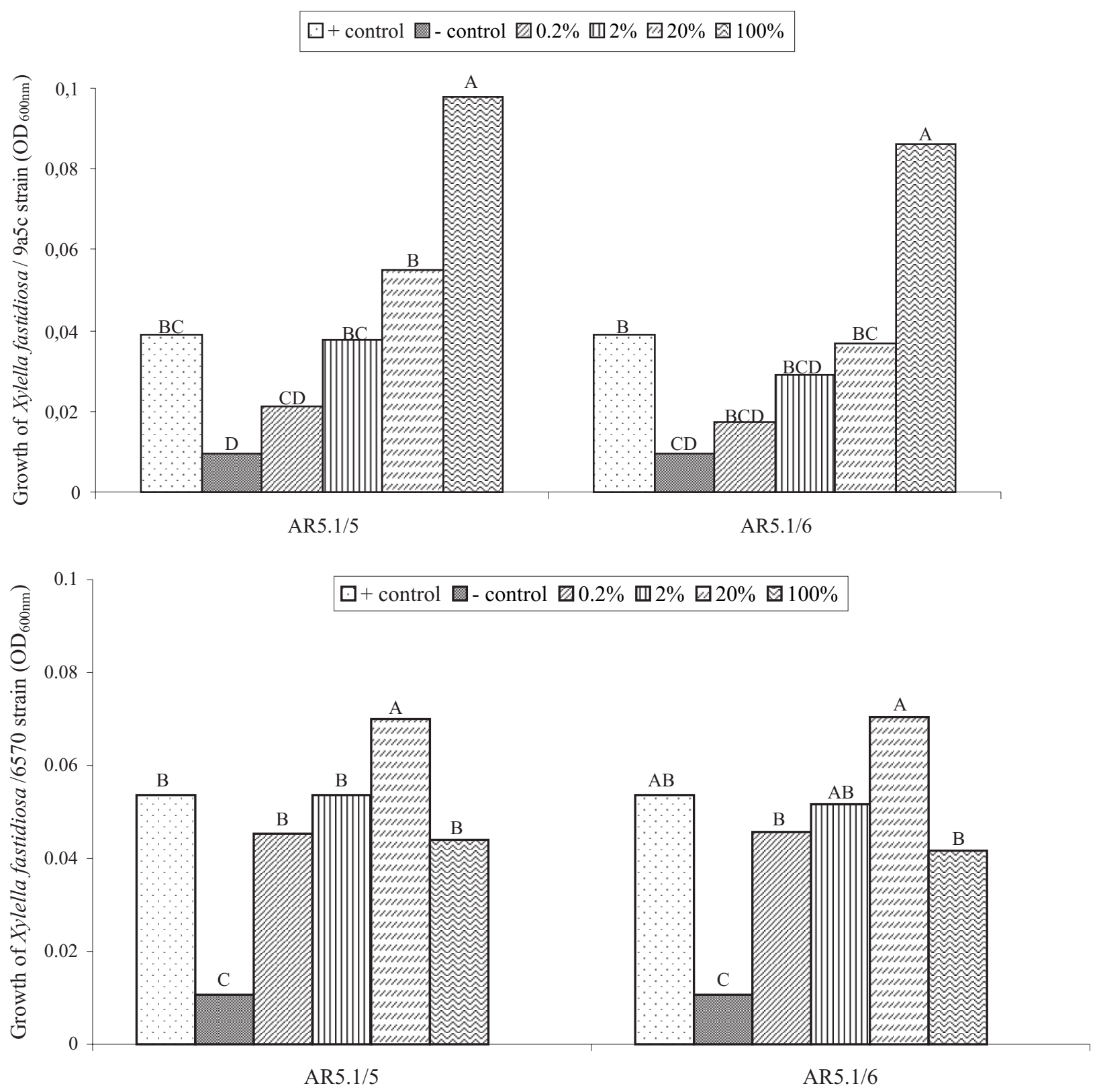

Figure 2. Effect of cell-free supernatants of the endophytic bacteria Methylobacterium mesophilicum (AR5.1/5 and AR5.1/6 strains) with siderophore production on the growth of Xylella fastidiosa subsp. pauca (9a5c and 6570 strains), in PW broth medium. The supernatants were individually tested by adding them to PW broth at a final concentration of $0.2,2,20,100 \%$ (v/v), inoculating the supplement PM broth with X. fastidiosa subsp. pauca, and evaluating growth spectrophotometrically at $\lambda=600 \mathrm{~nm}$, after 20 days. Negative control is represented by PW broth medium without a source of iron, and positive control by standard PW broth medium. Different letters on bars for the same treatment means statistic difference by Tukey's test, at $5 \%$ probability. 
symptoms. In this case, if $X f p$ is able to use siderophores produced by some strains of Methylobacterium in environmental conditions, there might be a strain-specific relationship between Xfp and some Methylobacterium strains isolated from citrus plants with CVC symptoms.

It was observed that Methylobacterium strains with high siderophore production were isolated from citrus plants in the same areas of São Paulo State (Table 1). This suggests that there is a correlation between where these strains were isolated and their production of siderophores.

The present data corroborates the hypotheses that there is a relationship between $X$. fastidiosa, the causal agent of $\mathrm{CVC}$, and the endophytic bacteria Methylobacterium (Araújo et al., 2002; Lacava et al., 2004). In addition, our results indicated that $X f p$ was able to use Methylobacterium siderophores in vitro, as source of iron (Figure 2), and suggested that in some instances Methylobacterium could help the growth of $X f p$, particularly under environmental conditions, where iron sources are limited. Siderophore complexes are taken up by specific transport systems, but some microorganisms have also developed transport systems for heterologous siderophores produced by other species (Raaijmakers et al., 1995).

Many of the important processes of X. fastidiosa, related to the diseases that it causes, probably rely on proteins such as hemolysins, adhesins, xantham gumproducing enzymes, virulence factors, and detoxification enzymes involved in one way or another with transport. This calls attention to transport proteins (Meidanis et al., 2002). Membrane receptors were reported from the Xfp genome sequence, including siderophores, ferrichromeiron and hemin receptors that are all associated with iron transport. The energizing complexes, TonB-ExbBExbD and the paralogous TolA-TolR-TolQ, essential for the functioning of the outer membrane receptors, were also present in Xfp genome. In all, 67 genes encoded proteins involved in the iron metabolism of Xfp (Simpson et al., 2000) and in iron sequestration might play an important role in leaf chlorosis, since this is the initial symptom of the disease (Silva-Stenico et al., 2005) caused by Xfp.

Endophytes must compete with plant cells for iron supply, therefore, siderophore production may be highly important for endophytic growth (Idris et al., 2004). Additionally, the production of siderophores has been reported to be one of the mechanisms to outcompete pathogens (O'Sullivan \& O'Gara, 1992), and may have the same function in endophytes. The present study suggested, as preliminary results, that $X f p$ can use molecules produced by endophytic bacteria as siderophores. In this context, as a factor influencing the symptom of CVC (Silva-Stenico et al., 2005; Pacheco et al., 2006), the genus Methylobacterium could help $X f p$ to survive inside the xylem vessels. However, additional studies are needed to provide a better understanding on the effect of iron availability in the production of siderophores by Methylobacterium spp., which could be involved in the iron-related virulence of the phytopathogen $X f p$.

\section{Conclusions}

1. Methylobacterium spp. have no ability of producing catechol-type siderophores, but are capable to produce hydroxamate-type siderophores.

2. In vitro growth of Xylella fastidiosa subsp. pauca is stimulated by the presence of a supernatantsiderophore of endophytic Methylobacterium mesophilicum.

\section{Acknowledgements}

To Fundação de Amparo à Pesquisa do Estado de São Paulo, for financial support and fellowship.

\section{References}

ARAÚJO, W.L.; MARCON, J.; MACCHERONI JÚNIOR, W.; ELSAS, J.D. van; VUURDE, J.W.L. van; AZEVEDO J.L. Diversity of endophytic bacterial populations and their interaction with Xylella fastidiosa in citrus plants. Applied and Environmental Microbiology, v.68, p.4906-4914, 2002.

ARNOW, L.E. Colorimetric determination of the components of 3,4-dihydroxyphenylalanine-tyrosine mixtures. Journal of Biological Chemistry, v.118, p.531-537, 1937.

AZEVEDO, J.L.; MACCHERONI JÚNIOR, W.; PEREIRA, J.O.; ARAÚJO, W.L. Endophytic microorganisms: a review on insect control and recent advances on tropical plants. Electronic Journal of Biotechnology, v.3, p.40-65, 2000.

BANUETT, F. Genetics of Ustilago maydis, a fungal pathogen that induces tumors in maize. Annual Review of Genetics, v.29, p.179-208, 1995.

CSÁKY, T.Z. On the estimation of bound hydroxylamine in biological materials. Acta Chemica Scandinavica, v.2, p.450-454, 1948.

DAVIS, M.J.; FRENCH, W.J.; SCHAAD, N.W. Axenic culture of the bacteria associated with phony disease of peach and plum leaf scald. Current Microbiology, v.6, p.425-314, 1981. 
DIARRA, M.S.; DOLENCE, E.K.; DARWISH, I.; MILLER, M.J.; MALOUIN, F.; JACQUES, M. Growth of Actinobacillus pleuropneumoniae is promoted by exogenous hydroxamate and catechol siderophores. Applied and Environmental Microbiology, v.62, p.853-859, 1996.

ETCHEGARAY, A.; SILVA-STENICO, M.E.; MOON, D.H.; TSAI, S.M. In silico analysis of nonribosomal peptide synthetases of Xanthomonas axonopodis pv. citri: identification of putative siderophore and lipopeptide biosynthetic genes. Microbiological Research, v.159, p.425-437, 2004.

IDRIS, R.; TRIFONOVA, R.; PUSCHENREITER, M.; WENZEL, W.W.; SESSITSCH, A. Bacterial communities associated with flowering plants of the Ni hyperaccumulator Thlaspi goesingense. Applied and Environmental Microbiology, v.70, p.2667-2677, 2004.

IMBERT, M.; BÉCHET, M.; BLONDEAU, R. Comparison of the main siderophores produced by some species of Streptomyces. Current Microbiology, v.31, p.129-133, 1995.

KOSTER, M.; OVAA, W.; BITTER, W.; WEISBEEK, P. Multiple outer membrane receptors for uptake of ferric pseudobactins in Pseudomonas putida WCS358. Molecular and General Genetics, v.248, p.735-743, 1995.

LACAVA, P.T.; ANDREOTE, F.D.; ARAÚJO, W.L.; AZEVEDO, J.L. Caracterização da comunidade bacteriana endofítica de citros por isolamento, PCR específico e DGGE. Pesquisa Agropecuária Brasileira, v.41, p.637-642, 2006a.

LACAVA, P.T.; ARAÚJO, W.L.; MARCON, J.; MACCHERONI JÚNIOR, W.; AZEVEDO, J.L. Interaction between endophytic bacteria from citrus plants and the phytopathogenic bacteria Xylella fastidiosa, causal agent of citrus-variegated chlorosis. Letters in Applied Microbiology, v.39, p.55-59, 2004.

LACAVA, P.T.; LI, W.B.; ARAÚJO, W.L.; AZEVEDO, J.L.; HARTUNG, J.S. Rapid, specific and quantitative assays for the detection of the endophytic bacterium Methylobacterium mesophilicum in plants. Journal of Microbiological Methods, v.65, p.535-541, 2006b.

LACAVA, P.T.; LI, W.B.; ARAÚJO, W.L.; AZEVEDO, J.L.; HARTUNG, J.S. The endophyte Curtobacterium flaccumfaciens reduces symptoms caused by Xylella fastidiosa in Catharanthus roseus. The Journal of Microbiology, v.45, p.388-393, 2007.

LOPER, J.E.; HENKELS, M.D. Utilization of heterologous siderophores enhances levels of iron available to Pseudomonas putida in the rhizosphere. Applied and Environmental Microbiology, v.65, p.5357-5363, 1999.

MARTINEZ, J.L.; DELGADO-IRIBARREN, A.; BAQUERO, F. Mechanisms of iron acquisition and bacterial virulence. FEMS Microbiology Reviews, v.75, p.45-56, 1990.

MARUCCI, R.C.; GIUSTOLIN, T.A.; MIRANDA, M.P.; MIQUELOTE, H.; ALMEIDA, R.P.P.; LOPES, J.R.S. Identification of a non-host plant of Xylella fastidiosa for rearing healthy sharpshooter vectors. Scientia Agricola, v.60, p.669-675, 2003.

MASCLAUX, C.; EXPERT, D. Signalling potential of iron in plant-microbe interactions: the pathogenic switch of iron transport in Erwinia chrysanthemi. Plant Journal, v.7, p.121128, 1995.

MEIDANIS, J.; BRAGA, M.D.V.; VERJOVSKI-ALMEIDA, S. Whole-genome analysis of transporters in the plant pathogen Xylella fastidiosa. Microbiology and Molecular Biology Reviews, v.66, p.272-299, 2002.

MEYER, J.M. Exogenous siderophore-mediated iron uptake in Pseudomonas aeruginosa: possible involvement of porin OprF in iron translocation. Journal of General Microbiology, v.138, p.951958, 1992.

NACHIN, L.; EL HASSOUNI, M.; LOISEAU, L.; EXPERT, D.; BARRAS, F. SoxR-dependent response to oxidative stress and virulence of Erwinia chrysanthemi: the key role of SufC, an orphan ABC ATPase. Molecular Microbiology, v.39, p.960-972, 2001.

NEILANDS, J.B.; NAKAMURA, K. Detection, determination, isolation, characterization and regulation of microbial iron chelates. In: WINKELMANN, G. (Ed.). CRC handbook of microbial iron chelates. Florida: CRC Press, 1991. p.1-14.

NUDEL, C.; GONZALEZ, R.; CASTANEDA, N.; MAHLER, G.; ACTIS, L.A. Influence of iron on growth, production of siderophore compounds, membrane proteins, and lipase activity in Acinetobacter calcoaceticus BD 413. Microbiological Research, v.155, p.263269, 2001.

O'SULLIVAN, D.J.; O'GARA, F. Traits of fluorescent Pseudomonas spp. involved in suppression of plant root pathogens. Microbiological Reviews, v.56, p.662-676, 1992.

PACHECO, F.T.H.; SILVA-STENICO, M.E.; ETCHEGARAY, A.; GOMES, J.E.; CARRILHO, E.; TSAI, S.M. Specific amplification of iron receptor genes in Xylella fastidiosa strains from different hosts. Genetics and Molecular Biology, v.29, p.137-141, 2006.

POOLE, K.; YOUNG, L.; NESHAT, S. Enterobactin-mediated iron transport in Pseudomonas aeruginosa. Journal of Bacteriology, v.172, p.6991-6996, 1990.

RAAIJMAKERS, J.M.; VAN DER SLUIS, I.; KOSTER, M.; BAKKER, P.A.H.M.; WEISBEEK, P.J.; SCHIPPERS, B. Utilization of heterologous siderophores and rhizosphere competence of fluorescent Pseudomonas spp. Canadian Journal of Microbiology, v.41, p.126-135, 1995.

SCHAAD, N.W.; POSTNIKOVA, E.; LACY, G.; FATMI, M.; CHANG, C.J. Xylella fastidiosa subspecies: X. fastidiosa subsp. piercei, subsp. nov., X. fastidiosa subsp. multiplex, subsp. nov., $X$. fastidiosa subsp. pauca, subsp. nov. Systematic and Applied Microbiology, v.27, p.290-300, 2004.

SCHWYN, B.; NEILANDS, J.B. Universal chemical assay for the detection and determination of siderophores. Analytical Biochemistry, v.160, p.47-56, 1987.

SHARMA, A.; JOHRI, B.N. Growth promoting influence of siderophore-producing Pseudomonas strains GRP3A and $\mathrm{PRS}_{9}$ in maize (Zea mays L.) under iron limiting conditions. Microbiological Research, v.158, p.243-248, 2003.

SILVA-STENICO, M.E.; PACHECO, F.T.H.; RODRIGUES, J.L.M.; CARRILHO, E.; TSAI, S.M. Growth and siderophore production of Xylella fastidiosa under iron-limited conditions. Microbiological Research, v.160, p.429-436, 2005. 
SIMIONATO, A.V.C.; SIMÓ, C.; CIFUENTES, A.; LACAVA, P.T.; ARAÚJO, W.L.; AZEVEDO, J.L.; CARRILHO, E. Capillary electrophoresis-mass spectrometry of citrus endophytic bacteria siderophores. Electrophoresis, v.27, p.2567-2574, 2006.

SIMPSON, A.J.G.; REINACH, F.C.; ARRUDA, P.; ABREU, F.A.; ACENCIO, M.; ALVARENGA, R.; ALVES, L.M.C.; ARAYA, J.E.; BAIA, G.S.; BAPTISTA, C.S.; BARROS, M.H.; BONACCORSI, E.D.; BORDIN, S.; BOVÉ, J.M.; BRIONES, M.R.S.; BUENO, M.R.P.; CAMARGO, A.A.; CAMARGO, L.E.A.; CARRARO, D.M.; CARRER, H.; COLAUTO, N.B.; COLOMBO, C.; COSTA, F.F.; COSTA, M.C.R.; COSTA-NETO, C.M.; COUTINHO, L.L.; CRISTOFANI, M.; DIAS-NETO, E.; DOCENA, C.; EL-DORRY, H.; FACINCANI, A.P.; FERREIRA, A.J.S.; FERREIRA, V.C.A.; FERRO, J.A.; FRAGA, J.S.; FRANÇA, S.C.; FRANCO, M.C.; FROHME, M.; FURLAN, L.R.; GARNIER, M.; GOLDMAN, G.H.; GOLDMAN, M.H.S.; GOMES, S.L.; GRUBER, A.; HO, P.L.; HOHEISEL, J.D.; JUNQUEIRA, M.L.; KEMPER, E.L.; KITAJIMA, J.P.; KRIEGER, J.E.; KURAMAE, E.E.; LAIGRET, F.; LAMBAIS, M.R.; LEITE, L.C.C.; LEMOS, E.G.M.; LEMOS, M.V.F.; LOPES, S.A.; LOPES, C.R.; MACHADO, J.A.; MACHADO, M.A.; MADEIRA, A.M.B.N.; MADEIRA, H.M.F.; MARINO, C.L.; MARQUES, M.V.; MARTINS, E.A.L.; MARTINS, E.M.F.; MATSUKUMA, A.Y.; MENCK, C.F.M.;
MIRACCA, E.C.; MIYAKI, C.Y.; MONTEIRO-VITORELLO, C.B.; MOON, D.H.; NAGAI, M.A.; NASCIMENTO, A.L.T.O.; NETTO, L.E.S.; NHANI JÚNIOR, A.; NOBREGA, F.G.; NUNES, L.R.; OLIVEIRA, M.A.; OLIVEIRA, M.C. de; OLIVEIRA, R.C. de; PALMIERI, D.A.; PARIS, A.; PEIXOTO, B.R.; PEREIRA, G.A.G.; PEREIRA, H.A.; PESQUERO, J.B.; QUAGGIO, R.B.; ROBERTO, P.G.; RODRIGUES, V.; ROSA, A.J. de M.; ROSA, V.E. de; SÁ, R.G. de; SANTELLI, R.V.; SAWASAKI, H.E.; SILVA, A.C.R. da; SILVA, A.M. da; SILVA, F.R. da; SILVA, W.A.; SILVEIRA, J.F. da; SILVESTRI, M.L.Z.; SIQUEIRA, W.J.; SOUZA, A.A. da; SOUZA, A.P. de; TERENZI, M.F.; TRUFFI, D.; TSAI, S.M.; TSUHAKO, M.H.; VALLADA, H.; VAN SLUYS, M.A.; VERJOVSKI-ALMEIDA, S.; VETTORE, A.L.; ZAGO, M.A.; ZATZ, M.; MEIDANIS, J.; SETUBAL, J.C. The genome sequence of the plant pathogen Xylella fastidiosa. Nature, v.406, p.151-157, 2000.

SOUZA, A.A. de; TAKITA, M.A.; PEREIRA, E.O.; COLETTA-FILHO, H.D.; MACHADO, M.A. Expression of pathogenicity-related genes of Xylella fastidiosa in vitro and in planta. Current Microbiology, v.50, p.223-228, 2005.

WINKELMANN, G. Specificity of iron transport in bacteria and fungi. In: WINKELMANN, G. (Ed.). CRC handbook of microbial iron chelates. Florida: CRC Press, 1991. p.65-105.

Received on January 4, 2008 and accepted on April 18, 2008 